\title{
THIOL OXIDASE ABILITY OF COPPER ION IS SPECIFICALLY RETAINED UPON CHELATION BY ALDOSE REDUCTASE
}

Francesco Balestri, Roberta Moschini, Mario Cappiello, Umberto Mura and Antonella DelCorso.

University of Pisa, Department of Biology, Biochemistry Unit, via San Zeno, 51, Pisa, 56123 , Italy.

\section{Corresponding author:}

Antonella Del-Corso, University of Pisa, Department of Biology, Biochemistry Unit, via San Zeno, 51, Pisa, 56123, Italy; Phone: +39.050.2211454; Fax: +39.050.2211460

E-mail: antonella.delcorso@unipi.it

Acknowledgements. This work was supported by Pisa University, PRA 2015. We are indebted to Dr. G. Pasqualetti and Dr. R. Di Sacco (veterinary staff of Consorzio Macelli S. Miniato, Pisa) for their valuable co-operation in the bovine lenses collection. 


\begin{abstract}
Bovine lens aldose reductase is susceptible to a copper mediated oxidation, leading to the generation of a disulfide bridge with the concomitant incorporation of two equivalents of the metal and inactivation of the enzyme. The metal complexed by the protein remains redoxactive, being able to catalyze the oxidation of different physiological thiol compounds. The thiol oxidase activity displayed by the enzymatic form carrying one equivalent of copper ion $\left(\mathrm{Cu}_{1}-\mathrm{AR}\right)$ has been characterized. The efficacy of $\mathrm{Cu}_{1}-\mathrm{AR}$ in catalyzing thiol oxidation is essentially comparable to the free copper in terms of both thiol concentration and $\mathrm{pH}$ effect. On the contrary, the two catalysts are differently affected by temperature. The specificity of the AR-bound copper towards thiols is highlighted being $\mathrm{Cu}_{1}$-AR completely ineffective in promoting the oxidation of both low density lipoprotein and ascorbic acid.
\end{abstract}

Keywords: aldose reductase; copper; oxidative stress; thiol oxidase; 


\section{Introduction}

The role of transition metals in inducing cell damage has been widely recognized [1,2]. They promote the generation of reactive oxygen species (ROS), thus leading to oxidative stress which represents a co-causative factor in several pathological states linked to proteins, lipids and nucleic acid damage [3-8].

Copper ion is one of the most active transition metals in eliciting ROS generation. Given that it is the cofactor of several enzyme systems $[9,10]$, copper plays an important role as a trace element, thus making its deficiency detrimental for living cells [11, 12]. On the other hand, the fact that copper promotes ROS production through the Fenton reaction, means that it is important to control cellular levels of copper to prevent metal toxicity. Several protein systems (i.e. transporter, storage proteins and $\mathrm{Cu}$-chaperones) have thus evolved to regulate the uptake, distribution and delivery of copper [13-17]. Despite this strict control, diseases characterized by abnormally either elevated or low copper levels have been described, such as Wilson or Menkes disease, respectively [18]. Recently it has been postulated that elevated free copper levels may predict the risk for the onset of diabetes and Alzheimer disease [19].

The binding of copper to proteins normally warrants the maintenance of the metal in a redox inactive form, in order to avoid metal-catalyzed oxidation of cell components. However, prooxidant features of copper-binding proteins, such as superoxide dismutase, caeruloplasmin and $\beta$ amyloid, have been documented [20-23].

Despite not being a metal binding protein, aldose reductase (alditol: NADP ${ }^{+}$oxidoreductase, EC 1.1.1.21) (AR) is extremely sensitive to $\mathrm{Cu}(\mathrm{II})$, which overall seems to act as a tightly binding modifying agent. In fact, AR from bovine lens has been shown to be readily inactivated in the presence of stoichiometric amounts of the metal through an oxygen independent modification [24]. The loss of activity relies on the formation of a disulphide bridge between Cys298 and Cys303, and is accompanied by the incorporation of two equivalents of copper per enzyme mol [24, 25]. Molecular modelling studies [25] indicated that, of these two copper ions, one was completely embedded in the protein, while the other resulted free to interact with water molecules. Moreover, these studies suggested an active role of Thr113, Trp111 and Leu 300 in the interaction between AR and the copper ion embedded in the protein structure. These predictions were consistent with the observation that only one of the two copper ions can be detected by direct bathocuproine titration, while the second copper ion resulted accessible to bathocuproine only after prolonged thermal 
treatment of the copper-modified AR in the presence of either reducing or chelating agents [24].

In this paper, we report that the copper bound to AR remains redox active toward thiol compounds, but not toward other copper sensitive targets (i.e. ascorbic acid and low density lipoprotein), thus making the copper-modified AR able to act as a thiol oxidase.

\section{Materials and Methods}

\section{Materials}

Bathocuproinedisulfonic acid (BCDS), cysteine, CysGly, dithiothreitol (DTT), reduced glutathione (GSH), glutathione disulfide (GSSG), homocysteine, human low density lipoprotein (LDL), NADPH, penicillamine, monothioglycerol, $\gamma$-glutamylcysteine, cysteamine, thiobarbituric acid (TBA), D,L-glyceraldehyde (GAL), ascorbic acid (AA), ascorbate oxidase from Cucurbita sp (E.C. 1.10.3.3) were from Sigma-Aldrich. All other chemicals were of reagent grade from BDH Chemicals.

Enzymatic assay and purification of aldose reductase. Aldose reductase activity was measured at $37^{\circ} \mathrm{C}$ as previously described [26] using GAL as a substrate. The enzyme was purified from bovine lens as previously described [27]. The pure enzyme (1.2 U/mg) was stored at $4^{\circ} \mathrm{C}$ in $10 \mathrm{mM}$ sodium phosphate buffer $\mathrm{pH} 7.0$ (S-buffer) containing $2 \mathrm{mM}$ DTT. The molar concentration of AR was calculated on the basis of a molecular mass of $34 \mathrm{kDa}$, and of the protein concentration determined by the Coomassie Blue binding assay [28] performed using bovine serum albumin as a standard.

Preparation of copper-modified AR. The copper-modified AR was prepared as described [24], by incubating at $25^{\circ} \mathrm{C}$ in the S-buffer the purified bovine lens enzyme (3.5 $\mu \mathrm{M}$ final concentration), after an extensive dialysis against the S-buffer, in the presence of a 2.5 fold molar excess of $\mathrm{CuCl}_{2}$. After 90 min of incubation, the enzyme (which displayed a residual activity of about $15 \%$ compared to the native enzyme) was again dialyzed against S-buffer and stored at $4{ }^{\circ} \mathrm{C}$ for no more than two days. As expected [24], this enzyme form $\left(\mathrm{Cu}_{2}-\mathrm{AR}\right)$ contained two equivalents of copper as determined by complexometric titration (see below). Preparation of glutathione-modified aldose reductase. AR carrying a mixed disulphide with glutathione at the level of Cys298 (GS-AR) was prepared as previously described [29] upon incubation of $3.5 \mu \mathrm{M}$ native $\mathrm{AR}$ for $3 \mathrm{~h}$ at $25^{\circ} \mathrm{C}$ with $1.5 \mathrm{mM} \mathrm{GSSG}$, followed by extensive dialysis against the S-buffer.

Evaluation of LDL oxidation. LDL oxidation was detected essentially according to Yagi [30]. LDL was suspended ( $2 \mathrm{mg} / \mathrm{mL})$ in S-buffer and then dialyzed against the same buffer 
in order to remove the ethylenediamine tetraacetic acid (EDTA) present in the commercial preparation. Dialyzed LDL was incubated $(70 \mu \mathrm{g} / \mathrm{mL})$ in S-buffer at $37^{\circ} \mathrm{C}$ alone or in the presence of $1 \mu \mathrm{M}$ of either $\mathrm{CuCl}_{2}$ or $\mathrm{Cu}_{1}$-AR. At appropriate times (from 0 to $5 \mathrm{~h}$ ), aliquots of $400 \mu \mathrm{L}$ were withdrawn and $10 \mu \mathrm{L}$ of $10 \mathrm{mM}$ EDTA and $1 \mathrm{~mL}$ of $10 \%$ trichloroacetic acid were added. After the addition of $1 \mathrm{~mL}$ of $0.67 \%$ TBA, samples were incubated at $95^{\circ} \mathrm{C}$ for $2 \mathrm{~h}$ and, after cooling, the fluorescence at $554 \mathrm{~nm}$ (excitation $525 \mathrm{~nm}$ ) was measured on a Jasco FP6500 spectrofluorimeter.

Other methods. The concentration of thiol compounds was determined by Ellman titration [31].

Copper concentration was determined by BCDS titration as previously described [24] using an extinction coefficient for the (BCDS) ${ }_{2} \mathrm{Cu}$ (I) complex of of $12,250 \mathrm{M}^{-1} \mathrm{~cm}^{-1}$, which was evaluated by calibration curves obtained using standard $\mathrm{CuCl}_{2}$ solutions. When the metal was measured on $\mathrm{Cu}-$ treated $\mathrm{AR}$, the increase in absorbance at $483 \mathrm{~nm}$ was followed at $25^{\circ} \mathrm{C}$ until no more increase was observed (approximately $120 \mathrm{~min}$ ). Calculation was done after subtraction of absorbance values observed for control samples containing the same concentration of native AR.

The concentration of ascorbic acid was determined by evaluating the decrease in the absorbance at $265 \mathrm{~nm}$ following the oxidation of AA upon the addition of $250 \mathrm{mU}$ of ascorbate oxidase. The extinction coefficient at $265 \mathrm{~nm}$, obtained using known concentration of ascorbic acid, was $12.6 \pm 0.9 \mathrm{mM}^{-1} \mathrm{~cm}^{-1}$.

Unless otherwise stated, all the data are expressed as the mean \pm standard deviation of at least four independent measurements. Statistical analysis was performed using GraphPad 6.0 Software.

\section{RESULTS AND DISCUSSION}

\section{Thiol oxidase ability of copper-modified AR}

An important aspect of the oxidative modification of $\mathrm{AR}$ induced by $\mathrm{Cu}$ (II) is the retention by the oxidized enzyme of two equivalents of copper, which are bound to the protein $\left(\mathrm{Cu}_{2}-\right.$ AR) with a different level of efficiency [24, 25]. In our study, while one copper ion was released in solution after the incubation of $3.5 \mu \mathrm{M} \mathrm{Cu}_{2}-\mathrm{AR}$ at $25{ }^{\circ} \mathrm{C}$ in S-buffer for $2 \mathrm{~h}$, the second metal ion was removed from the protein only by a dialysis against the S-buffer performed after a prolonged incubation (at least $3 \mathrm{~h}$ ) at $37^{\circ} \mathrm{C}$ in the presence of $5 \mathrm{mM}$ DTT. Both modifications occurring on $\mathrm{AR}$ upon $\mathrm{Cu}$ (II) treatment (i.e. the binding of the metal ion and the oxidation of protein thiols) were thus reversed. 
When $1 \mu \mathrm{M} \mathrm{Cu}_{2}-\mathrm{AR}$ was incubated at $25^{\circ} \mathrm{C}$ in $\mathrm{S}$ - buffer with $1 \mathrm{mM}$ cysteine, there was a decrease in the reduced thiol, evaluated by DTNB titration (Fig. 1). There was no significant oxidation of cysteine with either $1 \mu \mathrm{M}$ native AR or with a solution obtained after protein removal by ultrafiltration through an Amicon YM10 membrane of a freshly prepared $1 \mu \mathrm{M}$ $\mathrm{Cu}_{2}$-AR. The oxidation rate $(29 \pm 4 \mu \mathrm{M} / \mathrm{min})$ was approximately twofold the value measured, under the same conditions, with $1 \mu \mathrm{M} \mathrm{CuCl}_{2}(14 \pm 1 \mu \mathrm{M} / \mathrm{min})$. These results suggest that both copper ions of $\mathrm{Cu}_{2}-\mathrm{AR}$ remained active as catalysts of thiol oxidation. The removal of one copper ion upon incubation of $\mathrm{Cu}_{2}-\mathrm{AR}$ at $25^{\circ} \mathrm{C}$ for $2 \mathrm{~h}$ followed by dialysis against S-buffer led to the generation of an enzyme form carrying only one (1.0 \pm 0.1) copper ion per enzyme mol $\left(\mathrm{Cu}_{1}-\mathrm{AR}\right)$, as evaluated by complexometric analysis, which was still able to induce cysteine oxidation (Fig. 1). A rate of cysteine oxidation of $13 \pm 2$ $\mu \mathrm{M} /$ min was measured with $1 \mu \mathrm{M} \mathrm{Cu}_{1}$-AR, which was comparable with that measured the presence of $1 \mu \mathrm{M} \mathrm{CuCl}_{2}$.

In order to evaluate the contribution of protein moiety on the thiol oxidase ability of AR, the second copper ion was removed in not reducing conditions by dialysis against $\mathrm{S}$-buffer after a prolonged incubation $\left(3 \mathrm{~h}\right.$ at $37^{\circ} \mathrm{C}$ ) in S-buffer containing $1 \mathrm{mM}$ EDTA (data not shown). In this case, the removal of the metal left AR in an inactive status, both as aldose reductase and as thiol oxidase (Fig. 1). When this copper-depleted enzyme was incubated (3.5 $\mu \mathrm{M})$ with $\mathrm{CuCl}_{2}(8.75 \mu \mathrm{M})$ at a ratio of approximately 1 to 3 , it was able to bind approximately two $(1.8 \pm 0.2)$ equivalents of the metal per enzyme mol, thus regaining its ability to catalyze cysteine oxidation (data not shown). These results highlight the importance of copper as the triggering species for thiol oxidation, as the oxidized AR is simply a protein scaffold that reversibly binds the metal ion.

The significance of the disulphide between Cys298 and Cys303 occurring in $\mathrm{Cu}_{1}$-AR [25] for copper binding was tested using the glutathionylated AR. This enzyme form (GS-AR), characterized by the S-glutathionylation at Cys298 [32], the most accessible Cys residue of AR, generated by GSSG transthiolation on AR (see Methods) and found in the bovine lens undergoing oxidative stress [33], was used as a protein target for $\mathrm{Cu}(\mathrm{II})$ oxidation. The incubation for $2 \mathrm{~h}$ of $3.5 \mu \mathrm{M}$ GS-AR at $25^{\circ} \mathrm{C}$ in the presence of a 2.5 molar excess of $\mathrm{CuCl}_{2}$ led to a progressive inactivation of the enzyme, as occurred for the native AR (data not shown).

Copper evaluation on the inactive enzyme revealed the presence of approximately one $(1.1 \pm$ 0.2 ) equivalent of the metal ion per enzyme mol. When copper-modified GS-AR was used as a catalyst of CysGly oxidation, oxidation rates of $11 \pm 1 \mu \mathrm{M} / \mathrm{min}$ were measured, which 
were essentially the same values observed for equivalent concentrations of free copper in solution. This suggests that the structural restraints linked to the intramolecular disulphide on $\mathrm{Cu}_{1}$ - $\mathrm{AR}$ are not a key factor in copper binding.

\section{Kinetic features of thiol oxidation catalyzed by $C u_{1}-A R$}

Due to the relatively easy release of the first copper ion from $\mathrm{Cu}_{2}-\mathrm{AR}$, it is conceivable that this copper ion may leave the enzyme, either wholly or partially, while acting as thiol oxidase and may exert its oxidant ability in solution. Thus, in order to evaluate the oxidant ability of the $\mathrm{AR}$ bound metal, $\mathrm{Cu}_{1}-\mathrm{AR}$ was used in further experiments. It is conceivable that the copper remaining in $\mathrm{Cu}_{1}-\mathrm{AR}$ was the ion that molecular modelling studies predicted as completely embedded in the protein structure [25]. The possible release of copper from $\mathrm{Cu}_{1}$-AR during incubation with different thiol compounds was tested and ruled out. In fact, the same rate of oxidation of cysteine was observed using both freshly prepared $\mathrm{Cu}_{1}-\mathrm{AR}$ and $\mathrm{Cu}_{1}$-AR recovered after the enzyme had been used as a catalyst of the complete oxidation of $1 \mathrm{mM}$ cysteine and then dialyzed against S-buffer.

Different thiols showed a different susceptibility to oxidation by $\mathrm{Cu}_{1}-\mathrm{AR}$, as occurs when using the free copper in solution. Also the $\mathrm{pH}$, as expected, affects the oxidation, being $\mathrm{pH} 8$ the optimal condition for oxidation for most of the tested thiols, except for cysteine and CysGly, whose maximal oxidation rates were observed at $\mathrm{pH} 7.4$ and 6.5, respectively. Table 1 reports the oxidation rates measured for different thiol compounds when incubated at $25^{\circ} \mathrm{C}$ at their optimal $\mathrm{pH}$ with $1 \mu \mathrm{M}$ of either $\mathrm{Cu}_{1}-\mathrm{AR}$ or $\mathrm{CuCl}_{2}$. For both catalysts, the values ranged within more than one order of magnitude between the oxidation rate of glutathione and homocysteine and the oxidation rate of cysteamine. The results underline the similarity of the thiol oxidative process in the presence of the two oxidation inducers (i.e. $\mathrm{Cu}_{1}$-AR and free copper ion). The only exception concerns Cys-Gly, which appeared to be slightly more susceptible to the oxidation induced by $\mathrm{Cu}_{1}$-AR compared to $\mathrm{CuCl}_{2}(29 \pm 5 \mu \mathrm{M} / \mathrm{min}$ versus $18 \pm 2 \mu \mathrm{M} / \mathrm{min}$ ). This difference was constantly observed at different $\mathrm{pH}$ values and at different concentrations (ranging from 0.25 to $2 \mu \mathrm{M}$ ) of both free and AR-bound copper (data not shown).

The substrate dependence of thiol oxidation catalyzed by $\mathrm{Cu}_{1}-\mathrm{AR}$ and $\mathrm{CuCl}_{2}$ was evaluated using cysteine as a target. The oxidation rate of cysteine increased with increasing thiol concentration, reaching an apparent saturation, as reported in Fig. 2. An apparent $K_{M}$ of 1.3 \pm 0.1 (SE) $\mathrm{mM}$ and a $V_{\max }$ of $25 \pm 3(\mathrm{SE}) \mu \mathrm{M} / \mathrm{min}$ were measured with $0.8 \mu \mathrm{M} \mathrm{Cu}_{1}$-AR. A similar result was obtained when $0.8 \mu \mathrm{M} \mathrm{CuCl}_{2}$ was used as catalyst. In this case, a 
concentration of cysteine leading to a half saturation of the oxidative process of $1.0 \pm 0.1$ (SE) $\mathrm{mM}$ and a maximal rate of oxidation of $28 \pm 1$ (SE) $\mu \mathrm{M} / \mathrm{min}$ were measured.

Temperature appeared to be the most effective parameter in discriminating the free copper from the AR-bound copper dependent thiol oxidation. The oxidation rate of cysteine was evaluated at temperatures in the range $25-40^{\circ} \mathrm{C}$, using both $\mathrm{Cu}_{1}-\mathrm{AR}$ and $\mathrm{CuCl}_{2}$ as catalysts (Fig. 3). In the range $20-33^{\circ} \mathrm{C}$, no differences were observed between the two catalysts. When the temperature was increased above $33^{\circ} \mathrm{C}$, the oxidation rate in the presence of $\mathrm{Cu}_{1^{-}}$ AR diverges, at $40^{\circ} \mathrm{C}$ reaching a value $(44 \pm 1 \mu \mathrm{M} / \mathrm{min})$ that accounts for an overall four-fold increase compared to the value measured at $25^{\circ} \mathrm{C}$. In the same conditions, the increase in temperature from 25 to $40^{\circ} \mathrm{C}$ in the presence of $\mathrm{CuCl}_{2}$ led to an increase in the rate of cysteine oxidation of only 1.3 fold.

Thiol oxidation induced by copper proceeds through the preliminary formation of complexes with different low molecular weight ligands, including the same thiol undergoing oxidation [34-37]. It is conceivable that the intramolecular copper complex characterizing $\mathrm{Cu}_{1}$ - $\mathrm{AR}$ is more stable than the intermolecular complexes that copper may form with cysteine undergoing oxidation, which may explain the observed difference.

\section{Target specificity of the oxidase activity of copper-bound AR}

The ability of copper bound to AR to act as a catalyst of the oxidation of other molecules, different from thiols, was investigated. The susceptibility of LDL to oxidative modification by $\mathrm{Cu}(\mathrm{II})$, a key step in the aetiology of atherosclerosis, is a well-known event, although the conditions governing the oxidative process are still under investigation [38-41]. Ascorbic acid is another target of copper dependent oxidation [42, 43]. In fact, ascorbic acid and $\mathrm{Cu}$ (II) represent a pro-oxidant cell-damaging system, in which the reducing features of ascorbic acid enhance the redox potential of the metal ion, thus favouring, in the presence of oxygen, ROS generation [44, 45]. Both LDL and ascorbate were used as targets to compare the oxidative trigger effect exerted by the free copper ion and the AR-bound metal. LDL and ascorbic acid were incubated with either $\mathrm{CuCl}_{2}$ or $\mathrm{Cu}_{1}-\mathrm{AR}$, at a final concentration of $1 \mu \mathrm{M}$. The results reported in Figs. $4 \mathrm{a}$ and b clearly show the complete inability of $\mathrm{Cu}_{1}$-AR to catalyze the oxidation of both LDL and ascorbic acid. Besides the oxidation potential of the metal ion bound to AR, as judged by its ability to oxidize thiols, it is evident that its action may be restricted. In particular, it is relevant that, when reduced thiols are added to copper modified AR, the generation of a mixed disulphide between the thiol and Cys298 has been described [25]. Thus, it is conceivable that this may be the first step in the interaction 
between $\mathrm{Cu}_{1}-\mathrm{AR}$ and the thiol compound and may represent the only way for a molecule to interact with a copper ion which is completely embedded in the protein scaffold. The copper ion trapped on the protein at an interactive, even though not bonding, distance from Cys 303 (the counterpart of Cys298 in the disulfide bridge) may act as an electron sink when the trans-thiolation between the exogenous thiol compound and the intramolecular disulfide takes place. This site must then be accessible to oxygen; even though no predictions can be made at this point for the mechanism of the electron transfer, oxygen reduction will ultimately be the driving force of the oxidative process. The above considerations may be the rationale of the insensitivity of ascorbic acid and LDL to the oxidant activity of the copper bound AR.

The ability of AR to efficiently interact with copper ion leads to a stable 1:1 copper:AR complex in which the redox potential of the bound metal ion is preserved. Thus, following $\mathrm{Cu}$ (II) treatment, the activity of AR is switched from the aldehyde reductase activity of the enzyme to a thiol oxidase activity. Indeed, except for the slight, but consistent, increase in susceptibility of Cys-Gly to oxidation and for the significant temperature effect observed with $\mathrm{Cu}_{1}-\mathrm{AR}$ with respect to free copper, the pro-oxidant activity of the AR-bound metal ion towards thiols does not appear to be especially enhanced with respect to the free metal ion. On the contrary, the metal ion retained by the oxidized enzyme appears to be less active in triggering oxidation of non-thiol targets. In fact, ascorbate and LDL, which are very susceptible to the oxidation promoted by free copper ion, are essentially preserved when copper is bound on AR. Thus, the AR protein appears adequate in controlling the prooxidant action of the metal ion in eliciting the oxidative stress phenomena of lipid peroxidation or ascorbate-dependent ROS generation. On the other hand, AR is apparently unable to buffer the redox ability of copper towards thiols. Thus, the generation of copper modified AR, which could occur in situations of abnormally elevated cellular copper levels, as those reported in Wilson disease [46] or in diabetes [47], might, through the reported prooxidant action of Cys and CysGly [48], ultimately promote glutathione oxidation.

Conflict of interest: The authors declare that they have no conflict of interest. 


\section{REFERENCES}

1. Halliwell B, Gutteridge JMC (1990) Role of free radicals and catalytic metal ions in human disease: an overview. Methods Enzymol 186:1-85.

2. Valko M, Morris H, Cronin MTD (2005) Metals, toxicity and oxidative stress. Curr Med Chem 12:1161-1208.

3. Halliwell B, Whiteman M (2004) Measuring reactive species and oxidative damage in vivo and in cell culture: how should you do it and what do the results mean?. Brit $\mathbf{J}$ Pharmacol 142:231-255.

4. Klaunig J, Kamendulis LM, Hocevar BA (2010) Oxidative stress and oxidative damage in carcinogenesis. Toxicol Pathol 38:96-109.

5. Telpoukhovskaia MA, Orvig C (2013) Werner coordination chemistry and neurodegeneration. Chem Soc Rev 42:1836-1846.

6. Uttara B, Singh AV, Zamboni P, Mahajan RT (2009) Oxidative stress and neurodegenerative diseases: a review of upstream and downstream antioxidant therapeutic options. Curr Neuropharmacol 7:65-74.

7. Van den Berghe PVE, Klomp LWJ (2010) Posttranslational regulation of copper transporters. J Biol Inorg Chem 15:37-46.

8. Velthuis NA Gaeth AP, Pearson RB, Gabriel K, Camakaris J (2009) The multi layered regulation of copper translocating P-type ATPases. Biometals 22:177-190.

9. Lutsenko S, Barnes NL, Bartee MY, Dymitriev OY (2007) Function and regulation of human copper-transporting ATPases. Physiol Rev 87:1011-1046.

10. Uriu-Adams JY, Keen CL (2005) Copper, oxidative stress, and human health. Mol Asp Med 26:268-298.

11. Church SJ, Begley P, Kureishy N, McHarg S, Bishop PN, Bechtold DA, Unwin RD, Cooper GJS (2015) Deficient copper concentrations in dried-defatted hepatic tissue from ob/ob mice: a potential model for study of defective copper regulation in metabolic liver disease. Biochem Biophys Res Commun 460:549-554.

12. Dalal N, Hooberman A, Mariani R, Sirota R, Lestingi T (2015) Copper deficiency mimicking myelodysplastic syndrome. Clin Case Rep 3:325-727.

13. Barry AN, Shinde U, Lutsenko S (2010) Structural organization of human Cutransporting ATPases: learning from building blocks. J Biol Inorg Chem 15:47-59.

14. Bauerly KA, Kelleher SL, Lonnerdal B (2005) Effects of copper supplementation on copper absorption, tissue distribution, and copper transporter expression in an infant rat model. Am J Physiol Gastrointest Liver Physiol 288:G1007- G1014. 
15. Davis SR, Cousins RJ (2000) Metallothionein expression in animals: a physiological perspective and functions. J Nutr 130:1085-1088.

16. Kuo YM, Gybina AA, Pyatskowit JW, Gitschier J, Prohaska JR (2006) Copper transport protein (Ctr1) levels in mice are tissue specific and dependent on copper status. J Nutr 136:21-26.

17. O’Halloran TV, Cizewski-Culotta V (2000) Metallochaperones, an intracellular shuttle service for metal ions. J Biol Chem 275:25057-25060.

18. de Bie P, Muller P, Wijmenga C, Klomp LW (2007) Molecular pathogenesis of Wilson and Menkes disease: correlation of mutations with molecular defects and disease phenotypes. $\mathrm{J}$ Med Genet 44:673-688.

19. Squitti R, Mendez AJ, Simonelli I, Ricordi C (2017) Diabetes and Alzheimer's disease: can elevated free copper predict the risk of the disease? J Alzheimers Dis. 56:1055-1064.

20. Ehrenwald E, Chisolm GM, Fox PL (1994) Intact human ceruloplasmin oxidatively modifies low density lipoprotein. J Clin Invest 93:1493-1501.

21. Opazo C, Huang X, Cherny RA, Moir RD, Roher AE, White AR, Cappai R, Masters CL, Tanzi RE, Inestrosa NC, Bush AI (2002) Metalloenzyme-like activity of Alzheimer's disease beta-amyloid. $\mathrm{Cu}$-dependent catalytic conversion of dopamine, cholesterol, and biological reducing agents to neurotoxic $\mathrm{H}_{2} \mathrm{O}_{2}$. J Biol Chem 277:40302-40308.

22. Winterbourn C, Peskin AV, Parsons-Mair HN (2002) Thiol oxidase activity of copper,zinc superoxide dismutase. J Biol Chem 277:1906-1911.

23. Yim MB, Yim HS, Chock PB, Stadtman ER (1998) Pro-oxidant activity of Cu,Znsuperoxide dismutase. Age 21:91-94.

24. Cecconi I, Moroni M, Vilardo PG, Dal Monte M, Borella P, Rastelli G, Costantino L, Garland D, Carper D, Petrash JM, Del Corso A, Mura U (1998) Oxidative modification of aldose reductase induced by copper ion. Factors and conditions affecting the process. Biochemistry 37:14167-14174.

25. Cecconi I, Scaloni A, Rastelli G, Moroni M, Vilardo PG, Costantino L, Cappiello M, Garland D, Carper D, Petrash JM, Del Corso A, Mura U. (2002) Oxidative modification of aldose reductase induced by copper ion. Definition of the metal-protein interaction mechanism. J Biol Chem 277:42017-42027.

26. Del-Corso A, Balestri F, Di Bugno E, Moschini R, Cappiello M, Sartini S, La-Motta C, DaSettimo F, Mura U. (2013) A new approach to control the enigmatic activity of aldose reductase. PLoS ONE Doi:10.1371/journal.pone.0074076. 
27. Moschini R, Marini I, Malerba M, Cappiello M, Del Corso A, Mura U (2006) Chaperone-like activity of alpha-crystallin toward aldose reductase oxidatively stressed by copper ion. Arch Biochem Biophys 453:13-7.

28. Bradford MM (1976) A rapid and sensitive method for the quantitation of microgram quantities of protein utilizing the principle of protein-dye binding. Anal Biochem 72:248254.

29. Cappiello M, Voltarelli M, Giannessi M, Cecconi I, Camici G, Manao G, Del Corso A, Mura U (1994) Glutathione dependent modification of bovine lens aldose reductase. Exp Eye Res 58:491-501.

30. Yagi K (1987) Lipid peroxides and human disease. Chem Phys Lipids 45:337-351.

31. Ellman GL (1959) Tissue sulfhydryl groups. Arch Biochem Biophys 82:70-77.

32. Cappiello M, Voltarelli M, Cecconi I, Vilardo PG, Dal Monte M, Marini I, Del Corso A, Wilson DK, Quiocho FA, Petrash JM, Mura U (1996) Specifically targeted modification of human aldose reductase by physiological disulfides. J Biol Chem 271:33539-33544.

33. Cappiello M, Vilardo PG, Cecconi I, Leverenz V, Giblin FJ, Del Corso A, Mura U. (1995) Occurrence of glutathione-modified aldose reductase in oxidatively stressed bovine lens. Biochem Biophys Res Commun 207:775-82.

34. Dokken KM, Parsons JG, McClure J, Gardea-Torresdey JL (2009) Synthesis and structural analysis of copper(II) cysteine complexes. Inorg Chim Acta 362:395-401.

35. Patterson RA, Lamb DJ, Leake DS (2003) Mechanisms by which cysteine can inhibit or promote the oxidation of low density lipoprotein by copper. Atherosclerosis 169:87-94.

36. Pecci L, Montefoschi G, Musci G, Cavallini D (1997) Novel findings on the copper catalyzed oxidation of cysteine. Amino Acids 13:355-367.

37. Ząbek-Adamska A, Drożdż R, Naskalski JW (2013) Dynamics of reactive oxygen species generation in the presence of copper(II)-histidine complex and cysteine. Acta Biochim Pol 60:565-571.

38. Burkitt MJ (2001) A critical overview of the chemistry of copper-dependent low density lipoprotein oxidation: roles of lipid hydroperoxides, $\alpha$-tocopherol, thiols, and ceruloplasmin. Arch Biochem Biophys 394:117-135.

39. Ghaffari MA, Ghiasvand T (2010) Kinetic study of low density lipoprotein oxidation by copper. Indian J Clin Biochem 25:29-36.

40. Sasabe N, Keyamura Y, Obama T, Inoue N, Masuko Y, Igarashi Y, Aiuchi T, Kato R, Yamaguchi T, Kuwata H, Iwamoto S, Miyazaki A, Hara S, Yoshikawa T, Itabe H (2014) 
Time course-changes in phosphatidylcholine profile during oxidative modification of lowdensity lipoprotein. Lipids Health Dis 13:48-61.

41. Ziouzenkova O, Sevanian A, Abuja PM, Ramos P, Esterbauer H (1998) Copper can promote oxidation of LDL by markedly different mechanisms. Free Radic Biol Med 24:607623.

42. Samocha-Bonet D, Lichtenberg D, Pinchuk I (2005) Kinetic studies of copper-induced oxidation of urate, ascorbate and their mixtures. J Inorg Biochem 99:1963-1972.

43. Xu J, Jordan RB (1990) Kinetics and mechanism of the reaction of aqueous copper with ascorbic acid. Inorg Chem 29:2933-2935.

44. Haase G, Dunkley WL (1969) Ascorbic acid and copper in linoleate oxidation. III.

Catalysts in combination. J Lipid Res 10:568-576.

45. Kano Y, Sakano Y, Fujimoto D (1987) Cross-linking of collagen by ascorbate-copper ion systems. J Biochem 102:839-842.

46. Pfeiffer RF (2007) Wilson's disease. Semin Neurol 27:123-132.

47. Aydin E, Cumurcu T, Ozugurlu F, Ozyurt H, Sahinoglu S, Mendil D, Hasdemir E (2005) Levels of iron, zinc, and copper in aqueous humor, lens, and serum in nondiabetic and diabetic patients: their relation to cataract. Biol Trace Elem Res. 108:33-41.

48. Del Corso A, Vilardo PG, Cappiello M, Cecconi I, Dal Monte M, Barsacchi D, Mura U (2002) Physiological thiols as promoters of glutathione oxidation and modifying agents in protein Sthiolation. Arch Biochem Biophys 397:392-398. 


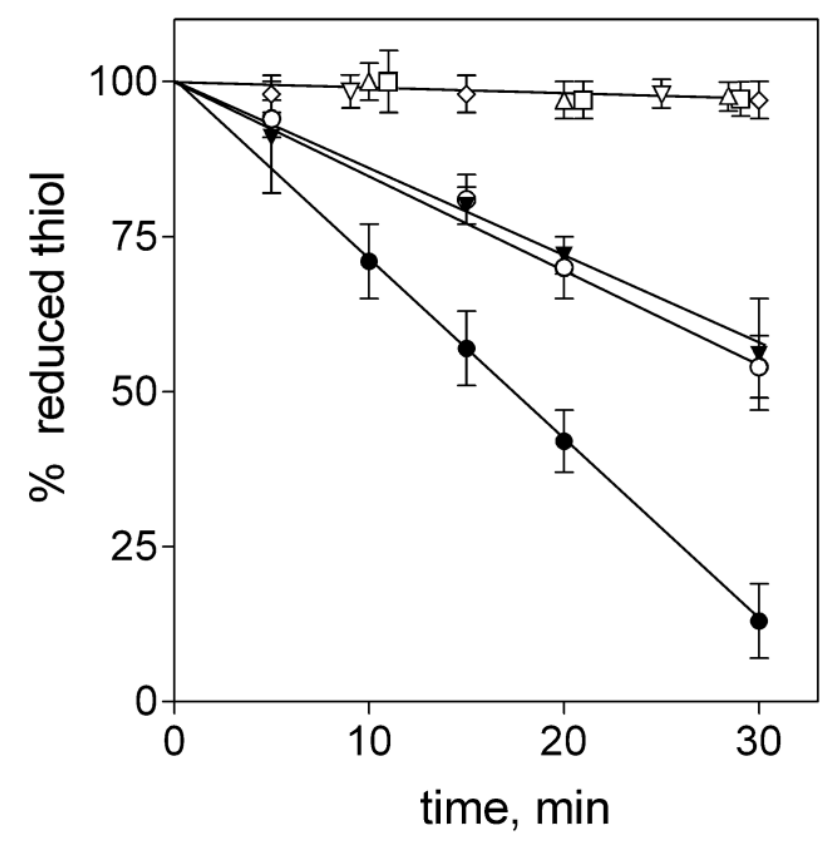

Figure 1 Cysteine oxidation induced by copper-modified aldose reductase. Cysteine $(1 \mathrm{mM})$ was incubated at $25^{\circ} \mathrm{C}$ in S-buffer in the presence of the following: none, $(\nabla) ; 1 \mu \mathrm{M} \mathrm{Cu}_{2^{-}}$ $\mathrm{AR},(\bullet) ; 1 \mu \mathrm{M} \mathrm{Cu}_{1}-\mathrm{AR},(\boldsymbol{\nabla}) ; 1 \mu \mathrm{M} \mathrm{CuCl}_{2},(\mathrm{O}) ; 1 \mu \mathrm{M}$ native $\mathrm{AR},(\triangle)$; solution obtained by ultrafiltration through an Amicon YM10 membrane of a freshly prepared $1 \mu \mathrm{M} \mathrm{Cu}_{2}-\mathrm{AR}$, $(\square) ; 1 \mu \mathrm{M} \mathrm{Cu}_{1}$-AR after EDTA treatment, $(\diamond)$. At different times, residual reduced thiol was evaluated through Ellman titration and reported as percent of the initial value. Error bars represent the standard deviation from three independent measurements 


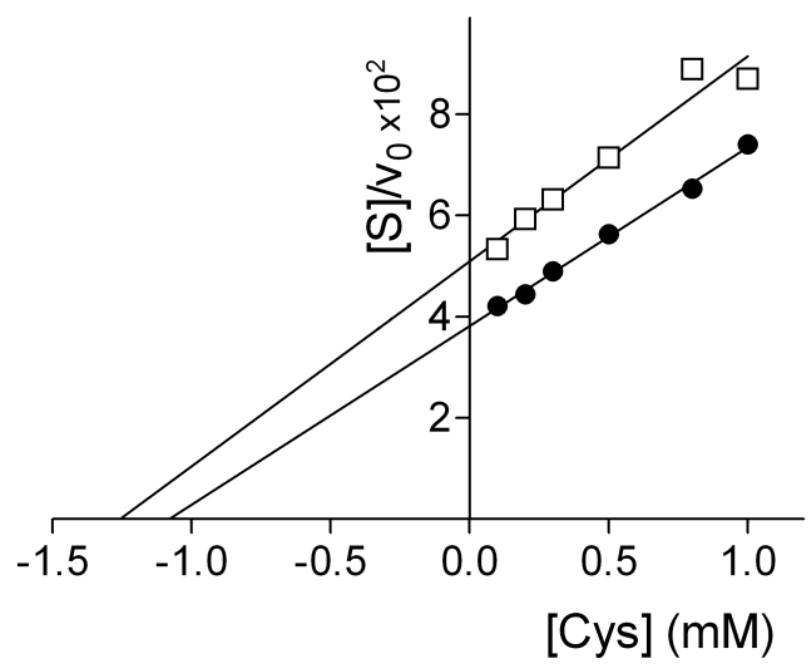

Figure 2 Effect of cysteine concentration on the thiol oxidation rate in the presence of ARbound copper or free copper ion. Different concentrations of cysteine were incubated at $25^{\circ} \mathrm{C}$ in $50 \mathrm{mM}$ sodium phosphate buffer $\mathrm{pH} 7.4$ in the presence of $0.8 \mu \mathrm{M}$ of either $\mathrm{Cu}_{1}$-AR $(\bullet)$ or $\mathrm{CuCl}_{2}(\square)$. At different times aliquots were withdrawn and the residual reduced thiol was evaluated. On the basis of measurements performed at 4 different times the oxidation rates were calculated and reported as a function of cysteine concentration. Data are reported as Hanes-Woolf plot; linear regression analysis was performed in order to estimate both the maximal rate of oxidation and the cysteine concentration leading to half saturation 


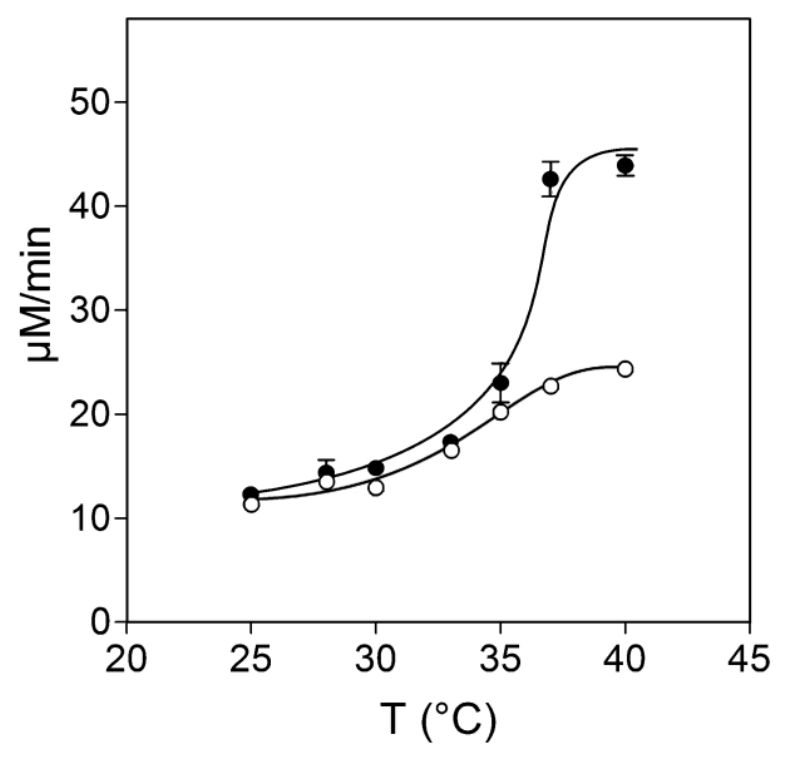

Figure 3 Effect of temperature on cysteine oxidation induce by AR-bound copper or free copper ion. Cysteine $(1 \mathrm{mM})$ was incubated in $50 \mathrm{mM}$ sodium phosphate buffer $\mathrm{pH} 7.4$ at the indicated temperatures in the presence of $1 \mu \mathrm{M}$ of either $\mathrm{Cu}_{1}-\mathrm{AR}(\bullet)$ or $\mathrm{CuCl}_{2}(\circ)$. At different times aliquots were withdrawn and the residual reduced thiol was evaluated. On the basis of measurements performed at 4 different times the oxidation rates were calculated and reported as a function of cysteine concentration. Error bars (when not visible are within the symbol size) represent the standard deviation from three independent measurements 

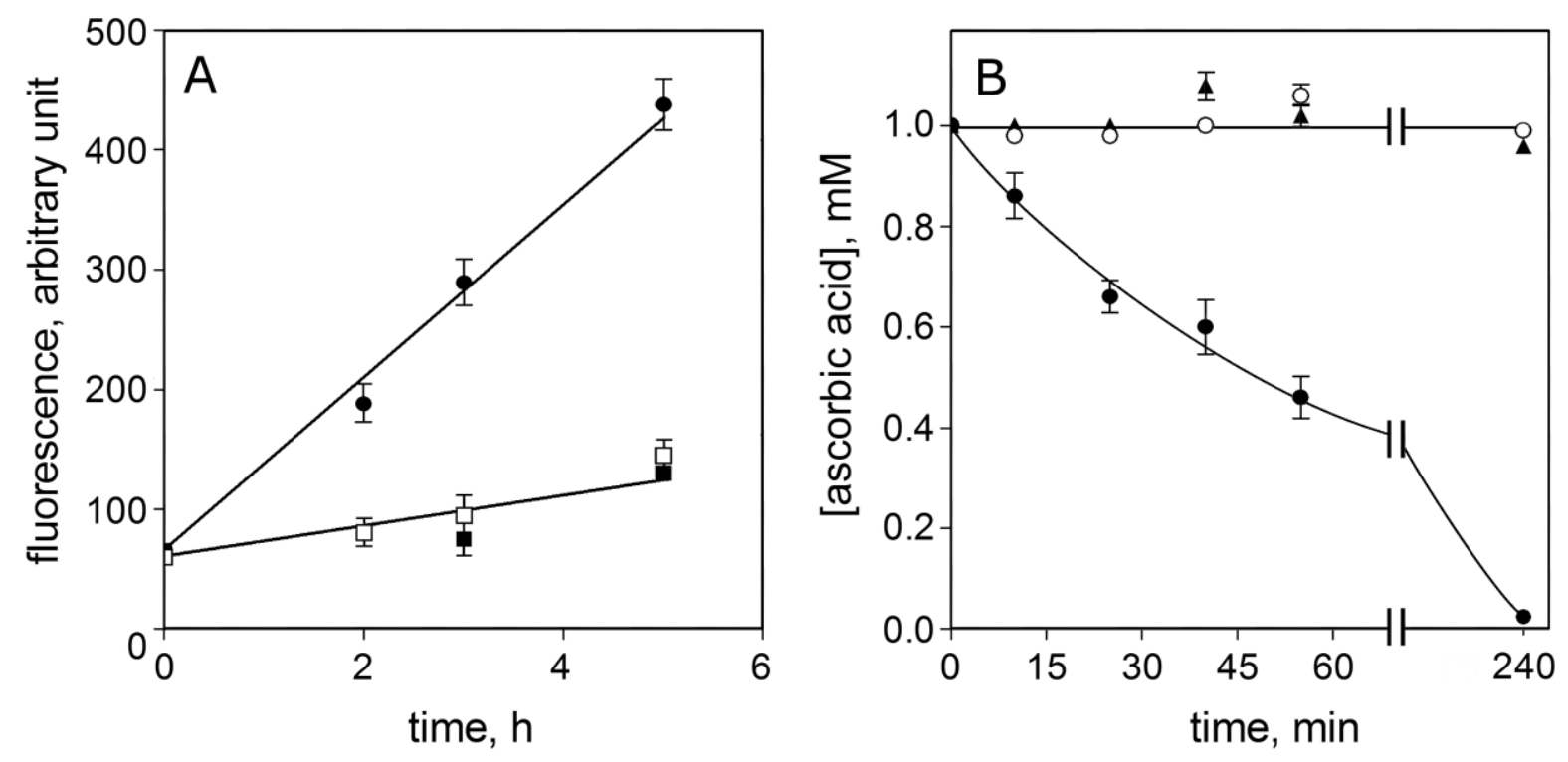

Figure 4 LDL and ascorbic acid are not oxidized by AR-bound copper. Panel $a$ : LDL were incubated $(70 \mu \mathrm{g} / \mathrm{mL})$ in S-buffer at $37^{\circ} \mathrm{C}$ alone ( $\left.\mathbf{}\right)$ or in the presence of $1 \mu \mathrm{M}$ of either $\mathrm{CuCl}_{2}(\bullet)$ or $\mathrm{Cu}_{1}-\mathrm{AR}(\square)$. At the indicated times aliquots were withdrawn for the evaluation of TBA reactive compounds (see Methods). Panel $b$ : ascorbic acid (1 mM) was incubated in S-buffer at $37^{\circ} \mathrm{C}$ alone $(\Delta)$ or in the presence of $1 \mu \mathrm{M}$ of either $\mathrm{CuCl}_{2}(\bullet)$ or $\mathrm{Cu}_{1}-\mathrm{AR}(\mathrm{O})$. At the indicated times aliquots were withdrawn for the evaluation of the residual ascorbic acid (see Methods). Error bars represent the standard deviation from three independent measurements 


\section{Table 1}

Oxidation rates of different thiols at optimal $\mathrm{pH}$ in the presence of $\mathrm{Cu}_{1}-\mathrm{AR}$ or $\mathrm{CuCl}_{2}$.

\begin{tabular}{|l|c|c|c|}
\hline Thiol compound & $\mathbf{p H}$ & $\mathbf{C u} \mathbf{1}-\mathbf{A R}$ & $\mathbf{C u C l}_{\mathbf{2}}$ \\
\hline Homocysteine & 8.0 & $0.6 \pm 0.1$ & $0.7 \pm 0.1$ \\
\hline Glutathione & 8.0 & $0.8 \pm 0.1$ & $0.6 \pm 0.2$ \\
\hline Monothioglycerol & 8.0 & $0.8 \pm 0.2$ & $0.8 \pm 0.1$ \\
\hline$\gamma$-Glu-Cys & 8.0 & $1.2 \pm 0.2$ & $1.8 \pm 0.1$ \\
\hline$\beta$-mercaptoethanol & 8.0 & $1.2 \pm 0.1$ & $1.0 \pm 0.1$ \\
\hline Penicillamine & $8.0 / 6.5$ & $1.5 \pm 0.2 / 1.2 \pm 0.1$ & $22 \pm 2$ \\
\hline Cysteine & 7.4 & $23 \pm 2$ & $18 \pm 2$ \\
\hline Cys-Gly & 6.5 & $29 \pm 5$ & $30 \pm 6$ \\
\hline Cysteamine & 8.0 & $37 \pm 2$ & $0.2 / 1.6 \pm 0.2$ \\
\hline
\end{tabular}

Different thiols were incubated ( $1 \mathrm{mM}$ final concentration) at $25^{\circ} \mathrm{C}$ in $50 \mathrm{mM}$ sodium phosphate buffer at the indicated $\mathrm{pH}$ in the presence of $1 \mu \mathrm{M}$ of either $\mathrm{Cu}_{1}-\mathrm{AR}$ or $\mathrm{CuCl}_{2}$. Oxidation rates (mean \pm standard deviation from at least three independent measurements) are expressed as $\mu \mathrm{M} / \mathrm{min}$. 